\title{
Effect of Vermicompost and Microbial Inoculants on Yield, Soil Fertility and Economics of Wheat under Rainfed Conditions
}

\author{
Muhammad Arsaln ${ }^{1}$, Sair Sarwar ${ }^{2 *}$, Rizwan Latif ${ }^{1}$, Junaid Nawaz Chauhdary ${ }^{3}$, Munazza Yousra ${ }^{2}$ and \\ Shahbaz Ahmad ${ }^{2}$
}

${ }^{1}$ Barani Agricultural Research Institute, Chakwal, Pakistan; ${ }^{2}$ Land Resources Research Institute, Pakistan; ${ }^{3}$ Water Management Research Centre, University of Agriculture Faisalabad, Pakistan.

Abstract | Integrated application of mineral fertilizers, organic amendments and microbial inoculants not only maximize the crop production and economic returns but also improve the soil health. A two years field study was conducted in the farm of Barani Agricultural Research Institute, Chakwal (32'55’33”N, 72 '43'30"E) to evaluate the integrated impact of vermicompost (VC) and microbial inoculants on wheat yield and economics. Eight treatments i.e., control; recommended dose of fertilizers (160:150:50) NPK in kg $\mathrm{ha}^{-1}$; VC@ $@ \mathrm{t} \mathrm{ha}{ }^{-1}$; PSB; Recommended fertilizers +VC @ 4t ha ${ }^{-1}$; Recommended fertilizers + PSB; VC @ $4 \mathrm{t} \mathrm{ha} \mathrm{h}^{-1}+\mathrm{PSB}$; Recommended fertilizers + VC @ 4t ha $\mathrm{h}^{-1}+\mathrm{PSB}$ were tested in the experiment using various combinations of vermicompost (VC) @ $4 \mathrm{t} \mathrm{ha}^{-1}$ and phosphorus solubilizing bacterial (PSB) as microbial inoculants along with recommended dose of NPK fertilizers (RDF) were applied at the time of sowing. The combined application of VC, PSB and RDF increased the wheat yield $2684 \mathrm{kgha}^{-1}$ and $3179 \mathrm{kgha}^{-1}$ while the yield recorded in control was 572 and $887 \mathrm{kgha}^{-1}$ for two consecutive years. Same trend was observed in other yield attributes i.e. no. of tillers $\mathrm{m}^{-2}$ (T8; 348, 352 vs control; 240, 238), spike length (T8; $12 \mathrm{~cm}, 14 \mathrm{~cm}$

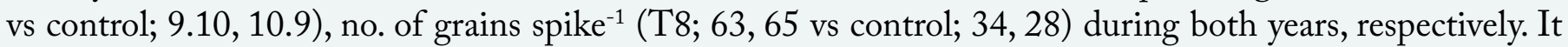
has also mended the soil health by improving the soil OM status $(0.58 \%), \mathrm{NO} 3-\mathrm{N}(13 \mathrm{ppm})$ and phosphorus $(9.4 \mathrm{ppm})$ contents. The economic analysis revealed that maximum net returns were found in integrated nutrient application (RDF, VC and microbial inoculants) i.e., Rs. 67,044 ha $\mathrm{h}^{-1}$ for 2017-18 and Rs. 1,03,202 $\mathrm{ha}^{-1}$ for 2 nd year and minimum returns in control.

Received | December 02, 2019; Accepted | September 22, 2020; Published | October 17, 2020

*Correspondence | Sair Sarwar, Land Resources Research Institute, Pakistan; Email: sardarsair@hotmail.com

Citation | Arsaln, M., S. Sarwar, R. Latif, J.N. Chauhdary, M. Yousra and S. Ahmad. 2020. Effect of vermicompost and microbial inoculants on yield, soil fertility and economics of wheat under rainfed conditions. Pakistan Journal of Agricultural Research, 33(4): 858-865.

DOI | http://dx.doi.org/10.17582/journal.pjar/2020/33.4.858.865

Keywords | Soil fertility, Wheat yield, Recommended dose of fertilizers (RDF), Vermicompost, Phosphorus solubilizing bacteria (PSB)

\section{Introduction}

W Theat (Tritium aestivum L.) is considered energetic dietary food among the cereal crops of Pakistan and occupies a major position in farming system (Anon, 2016). Wheat yield is being affected due to many factors like low rainfall, frost and heat hazards, imbalanced use of fertilizers, poor soil fertility and unaffordable cost of chemical fertilizers in barani areas. However, rust and water shortage are the major factors which are reducing wheat yield each year (Rahman et al., 2012; Ahmad et al., 2010; Shad et al., 1999).

Due to world energy crisis and highest prices of inorganic fertilizers, the application of organic sources as plant nutrients is gaining importance. Under such conditions, proper blending of both 
organic and inorganic materials is essential which improve yield and enhance soil fertility and health (Pullicinoa et al., 2009; Weber et al., 2007). Pakistan is facing many challenges like food and energy crisis, therefore to feed the growing population that is increasing@2.6\% every year, latest technologies of cultivation have to be explored to improve the yield (Qazilbash, 2002). Mineral fertilizers are powerful and immediate sources to meet the requirement, but the prices of inorganic chemical source are very high, non environment friendly and also unaffordable for poor farmers.

There are some other but little approaches available that can be adapted for the production of quality food. Maximum cultivated area is utilized for production of wheat in Pakistan than other crops therefor, wheat is considered the most important crop for Pakistani agriculture. Efficient organic resources should be focused in cereals especially in wheat to improve quality and production (Anon, 2007). The reduction of crop yield and soil fertility is due to the less application of bio-sources to soil (Shibu et al., 2010). Organic nutrient sources are caused by the carbon inputs (Lal, 2004), that has significant impact on various soil properties (Kumar and Goh, 1999). The application of composts and vermicompost (VC) as organic sources, except inorganic fertilizer and raw manure, enhance macro and micro nutrients, thereby ultimately improve soil health (Jack and Thies, 2006). Vermicomposting is aerobic, biological technique to convert organic wastes into fine form of organic substances. Application of organic compost and vermicompost boost the multiplication of microbes (nitrogen fixing bacteria and actinomycetes) and hence improve soil nitrogen and phosphorus (Chanda et al., 2011). Arslan et al. (2016) stated that the plant yield and nutrient uptake was enhanced by the application of vermicompost and full dose of phosphorus on mung bean. Livleen et al. (2013) while investigating the role of vermicompost and microbial inoculant on wheat also reported substantial increase in wheat yield in those treatments where organic and bio-sources were applied combinedly. The use of manures @10 tons $\mathrm{ha}^{-1}$ and vermicompost @ 5 tons ha ${ }^{-1}$ along with $60 \mathrm{~kg}$ $\mathrm{P}_{2} \mathrm{O}_{5} \mathrm{ha}^{-1}$, $\mathrm{PSB}$ and $40 \mathrm{~kg} \mathrm{~S} \mathrm{ha}^{-1}$ gave maximum yield of grain and straw (Patel et al. 2014). Kumar et al., (2017) also reported positive effect of vermicompost @ 5 tons $\mathrm{ha}^{-1}$ and phosphorus solubilizing bacteria on wheat yield and yield attributes. In view of the above facts, the experiment was designed to assess the consequence of organic and biological sources in the form of vermicompost and microbial inoculants along with inorganic nutrients on soil health and wheat yield under rainfed conditions.

\section{Materials and Methods}

A two years field study was conducted to assess the integrated effect of vermicompost, microbial inoculation and mineral fertilization on growth and yield of wheat cultivar Barani-17 at Barani Agricultural Research Institute (BARI), Chakwal (32'55'33”N, $72{ }^{\circ} 43^{\prime} 30^{\prime}$ E) during 2017-18 to 2018-19 with the mean rain fall during monsoon season for $2017-18$ and $2018-19$ was $210 \mathrm{~mm}$ and $140 \mathrm{~mm}$ respectively. Soil samples were collected prior to sowing at two depths of $0-15 \mathrm{~cm}$ and $15-$ $30 \mathrm{~cm}$ using soil sampler and analyzed for soil texture (Hydrometer method) $\mathrm{pH} / \mathrm{EC}$ (US Salinity lab staff, 1954), Organic matter (Walkley, 1947), available Nitrogen (Bremner et al., 1965), available phosphorus (Olsen et al., 1954) and available potassium (flame photometer method) in soil science lab of BARI, Chakwal. Soil $\mathrm{pH}$ was neutral to slightly alkaline as 7.6, non-saline EC 0.78 $\mathrm{dSm}^{-1}$, low in organic matter $0.31 \%$, poor available nitrogen $\left(3 \mathrm{mg} \mathrm{kg}^{-1}\right)$ and low available phosphorus $\left(2.5 \mathrm{mg} \mathrm{kg}^{-1}\right)$ and medium in available potassium $\left(110 \mathrm{mg} \mathrm{kg}^{-1}\right)$. The texture of soil was clay loam with low moisture contents 3\% (Gravimetric method) in upper layer (0-6 inch) and 7.2\% in lower layer (612 inch). Well prepared vermicompost was obtained from vermiculture unit existing at BARI that was analyzed for mineral composition given in Table 1 and PSB inoculants were collected from Land Resources Research Institute, NARC Islamabad to evaluate the efficiency under rainfed condition of Chakwal. Fertilizer, vermicompost was applied at the time of sowing and wheat seed was inoculated with PSB prior to sowing. The experiment was laid out in RCBD factorial design using eight treatments e.g. $\mathrm{T}_{1}$ : control where fertilizer, vermicompost (VC) and PSB wat not applied, $\mathrm{T}_{2}$ : Recommended fertilizers (RF) of NPK (120:85:60) in $\mathrm{kg} \mathrm{ha}{ }^{-1}$ was applied (Department of Agriculture Govt. of Punjab), $\mathrm{T}_{3}$ : Vermicompost (VC) @ 4t ha ${ }^{1}, \mathrm{~T}_{4}$ : Phosphorus Solubilizing Bacteria (PSB), $\mathrm{T}_{5}$ : Recommended fertilizers $(\mathrm{RF})+\mathrm{VC} @ 4 \mathrm{t} \mathrm{ha}^{-1}, \mathrm{~T}_{6}$ : Recommended fertilizers $(\mathrm{RF})+\mathrm{PSB} ; \mathrm{T}_{7}: \mathrm{VC} @ 4 \mathrm{t}$ $\mathrm{ha}^{-1}+\mathrm{PSB}, \mathrm{T}_{8}$ : Recommended fertilizers $(\mathrm{RF})+\mathrm{VC}$ @ $4 \mathrm{t} \mathrm{ha}^{-1}+\mathrm{PSB}$. and three replications. The crop was 
sown with a single hand drill method maintaining row to row distance as $22.8 \mathrm{~cm}$ keeping each plot size of $3 \mathrm{mx} 10 \mathrm{~m}$. As $2^{\text {nd }}$ year study was conducted on the same experimental site where $1^{\text {st }}$ year was conducted hence, the residual effect of previously applied vermicompost on soil and crop yield was also assessed after two years study. Agronomic data on no. of tillers per square meter by counting no. of tillers, plant height $(\mathrm{cm})$ using meter rod, thousand grain weight $(\mathrm{g})$ by weighing balance, spike length (cm) by measuring scale and final yield $\left(\mathrm{kg} \mathrm{ha} \mathrm{ha}^{-1}\right.$ using weighing balance after harvest was recorded and analyzed statistically (stat 8.1) using Least Significant Difference (LSD) multiple range test $\mathrm{P} \leq 0.05$ (Steel, 1997). The benefit cost ratio (BC) was also determined for each treatment by calculating amount of total income and total cost of production.

$$
B: C=\frac{\text { Total Income }(R s .)}{\text { Cost of Production }(R s)}
$$

Layout of experimental plot

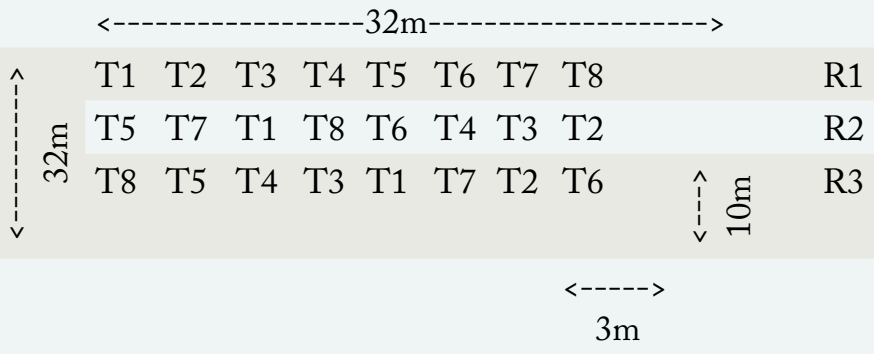

Table 1: Composition of vermicompost.

$\begin{array}{lll}\text { Parameters } & \text { Unit } & \text { Vermicompost } \\ \text { Organic carbon } & \% & 30 \\ \text { Nitrogen } & \% & 2 \\ \text { Phosphorus } & \% & 0.3 \\ \text { Potassium } & \% & 1.8 \\ \text { Magnesium } & \mathrm{mg} \mathrm{kg}^{-1} & 450 \\ \text { Zinc } & \mathrm{mg} \mathrm{kg}^{-1} & 150 \\ \text { Copper } & \mathrm{mg} \mathrm{kg}^{-1} & 45 \\ \text { Iron } & \mathrm{mg} \mathrm{kg}^{-1} & 1600 \\ \text { CN ratio } & & 16 \\ \text { pH } & & 6.8 \\ \text { Moisture } & \% & 27\end{array}$

\section{Results and Discussion}

\section{Plant height}

Results exhibited that all the parameter concerning wheat growth and yield were significantly affected by integrated application of vermicompost and microbial inoculants in combination with inorganic fertilizers (Table 2). For grain crops although plant height is not a yield constituent but it showed the impact of diverse nutrients on plant metabolism. Results indicated that when vermicompost and microbial inoculants in combination with inorganic fertilizers were applied it significantly increased in plant height over control. Maximum plant height $(95 \mathrm{~cm}, 96 \mathrm{~cm})$ during 2017-18 and 2018-19, was observed in plots where integrated organic, inorganic and biological sources $\left(\mathrm{T}_{8}\right)$ were applied. Minimum plant height $(81 \mathrm{~cm}$; $81 \mathrm{~cm}$ ) in both years was recorded in control. The plant height increases in response to integrated application might be mainly due supplementary contribution of nitrogen from different sources (Awan et al., 2011; Meena et al., 2003).

\section{No of tillers $/ m^{2}$}

The integrated application of vermicompost, PSB and RF significantly increased number of tillers $\mathrm{m}^{-2}$. The Highest number of tillers $\mathrm{m}^{-2}(348 ; 352)$ were found in $\mathrm{T}_{8}$ during 2017-18 and 2018-19, respectively. Control treatment $\left(\mathrm{T}_{1}\right)$ showed minimum tillers $\mathrm{m}^{-2}$ (240; 238) during both consecutive years. Optimum accessibility of the required nutrients may increase number of tillers (Brahmachari et al., 2011). The results also indicated that no. of tillers increased where appropriate amount of NPK and vermicompost was applied. This kind of trend may be due to the effect of VC and NPK that ultimately improve soil fertility during the two years, respectively. Maqsood et al. (2001) revealed that adequate application of NPK increased in number of tillers.

\section{Spike length}

A significant increase in spike length was found over control and maximum spike length $(12.3 \mathrm{~cm}$ and $14 \mathrm{~cm})$ was found in $\mathrm{T}_{8}$ treatment $(\mathrm{RF}+\mathrm{VC}+$ $\mathrm{PSB})$ whereas in control the spike length was only $9.1 \mathrm{~cm}$ and $11.9 \mathrm{~cm}$ during the years $2017-18$ and 2018-19, respectively. However, only slight difference in spike length was observed in all other treatments. These results may be due to the addition RF and vermicompost which improved nutrient status of soil. Dahiya et al. (2008) and Rather and Sharma (2010) also reported the similar findings in wheat. Increase in spike length in the treatment where organic and inorganic fertilizers were used collectively might be due to high availability of nutrients (Awan et al., 2011; Babu et al., 2001). 
Table 2: Effect of vermicompost, microbial inoculants and RF on agronomic parameters of wheat.

\begin{tabular}{|c|c|c|c|c|c|c|c|c|c|c|c|c|}
\hline \multirow[t]{2}{*}{ Trt. } & \multicolumn{2}{|c|}{ Plant height (cm) } & \multicolumn{2}{|c|}{$\begin{array}{l}\text { No. of tillers } \\
\left(\mathrm{m}^{-2}\right)\end{array}$} & \multicolumn{2}{|c|}{ Spike length (cm) } & \multicolumn{2}{|c|}{$\begin{array}{l}1000 \text { Grain } \\
\text { weight (g) }\end{array}$} & \multicolumn{2}{|c|}{$\begin{array}{l}\text { No. of grains } \\
\left(\text { spike }^{-1}\right)\end{array}$} & \multicolumn{2}{|c|}{ Grain yield $\left(\mathrm{Kg} \mathrm{ha}^{-1}\right)$} \\
\hline & $17-18$ & $18-19$ & $17-18$ & 18-19 & $17-18$ & $18-19$ & $17-18$ & $18-19$ & $17-18$ & $18-19$ & $17-18$ & $18-19$ \\
\hline $\mathrm{T}_{1}$ & $81 \mathrm{e}$ & $81 \mathrm{e}$ & $240 \mathrm{e}$ & $238 f$ & $9.10 \mathrm{e}$ & $10.9 \mathrm{e}$ & $29 \mathrm{~d}$ & $24 c$ & $34 \mathrm{e}$ & $28 \mathrm{e}$ & $572 \mathrm{e}$ & $887 f$ \\
\hline $\mathrm{T}_{2}$ & $88 \mathrm{~cd}$ & $91 \mathrm{abc}$ & $287 \mathrm{c}$ & $287 d$ & $10.7 \mathrm{c}$ & $12.7 \mathrm{~cd}$ & $37 \mathrm{c}$ & $37 \mathrm{~b}$ & $51 \mathrm{~cd}$ & $51 \mathrm{bcd}$ & $1963 b c$ & $1863 \mathrm{bcd}$ \\
\hline $\mathrm{T}_{3}$ & $88 \mathrm{~cd}$ & $88 \mathrm{~cd}$ & $248 \mathrm{e}$ & $250 \mathrm{f}$ & $10.4 \mathrm{~cd}$ & $12.4 \mathrm{~d}$ & $37 \mathrm{c}$ & $42 \mathrm{ab}$ & $47 d$ & $46 \mathrm{~d}$ & $1233 d$ & $1450 \mathrm{de}$ \\
\hline $\mathrm{T}_{4}$ & $90 \mathrm{bc}$ & $93 \mathrm{ab}$ & $266 \mathrm{~d}$ & $270 \mathrm{e}$ & $10 \mathrm{~d}$ & $12.0 \mathrm{~d}$ & $38 \mathrm{bc}$ & $37 \mathrm{~b}$ & $51 \mathrm{~cd}$ & $49 \mathrm{~d}$ & $1383 d$ & $1333 \mathrm{ef}$ \\
\hline $\mathrm{T}_{5}$ & $91 \mathrm{abc}$ & $90 \mathrm{bcd}$ & $319 b$ & $319 \mathrm{c}$ & $11.3 \mathrm{~b}$ & $13.3 \mathrm{bc}$ & $41 \mathrm{ab}$ & $42 \mathrm{ab}$ & $55 \mathrm{bc}$ & $55 \mathrm{bc}$ & $2033 b$ & $2311 b$ \\
\hline $\mathrm{T}_{6}$ & $93 \mathrm{ab}$ & $94 \mathrm{ab}$ & $328 \mathrm{~b}$ & $336 \mathrm{~b}$ & $11.7 \mathrm{~b}$ & $13.6 \mathrm{~b}$ & $40 \mathrm{abc}$ & $40 \mathrm{ab}$ & $59 \mathrm{ab}$ & $57 \mathrm{~b}$ & $1878 \mathrm{bc}$ & $2057 \mathrm{bc}$ \\
\hline $\mathrm{T}_{7}$ & 84de & $85 \mathrm{de}$ & $299 \mathrm{c}$ & $307 c$ & $10.1 \mathrm{~d}$ & $12.0 \mathrm{~d}$ & $38 \mathrm{bc}$ & $39 b$ & $50 \mathrm{~d}$ & $50 \mathrm{~cd}$ & $1594 \mathrm{~cd}$ & $1628 \mathrm{cde}$ \\
\hline $\mathrm{T}_{8}$ & $95 a$ & $96 a$ & $348 \mathrm{a}$ & $352 \mathrm{a}$ & $12.3 \mathrm{a}$ & $14.0 \mathrm{a}$ & $44 \mathrm{a}$ & $46 a$ & $63 a$ & $65 \mathrm{a}$ & $2484 \mathrm{a}$ & $3179 \mathrm{a}$ \\
\hline $\mathrm{CV}$ & 3.17 & 3.10 & 3.13 & 3.22 & 3.01 & 3.21 & 5.94 & 9.19 & 5.5 & 6.94 & 13 & 14 \\
\hline $\operatorname{LSD}^{(0.05)}$ & 5 & 5 & 16 & 17 & 0.56 & 0.71 & 4 & 6 & 5 & 6 & 372 & 463 \\
\hline
\end{tabular}

$T_{1}$ : control; $T_{2}$ : Recommended fertilizers (RF) of NPK (120:85:60) in kg ha ${ }^{-1} ; T_{3}:$ Vermicompost $(V C) @ 4 t$ ha ${ }^{-1} ; T_{4}$ : Phosphorus Solubilizing Bacteria (PSB); $T_{5}:$ Recommended fertilizers $(R F)+V C @ 4 t h a^{-1} ; T_{6}:$ Recommended fertilizers $(R F)+P S B ; T_{7}: V C @ 4 t h a^{-1}+P S B ; T_{8}:$ Recommended fertilizers $(R F)+V C @ 4 t h a^{-1}+P S B$.

\section{Grain weight}

Another main yield contributing parameter is the grain weight. The results showed that maximum thousand grain weight $\left(44 \mathrm{~g}\right.$ during $1^{\text {st }}$ year and $46 \mathrm{~g}$ during $2^{\text {nd }}$ year $)$ was found in the treatment $\mathrm{T}_{8}(\mathrm{RF}+$ $\mathrm{VC}+\mathrm{PSB}$ ) which was about $51 \%$ higher over control treatment that was only $29 \mathrm{~g}$ and $24 \mathrm{~g}$ in the two years study. However, the treatments $\mathrm{T}_{5}$ (Recommended fertilizer + vermicompost @ $4 \mathrm{t} \mathrm{ha}^{-1}$ ) also performed better than control showing $41 \mathrm{~g}$ during $1^{\text {st }}$ year and 42 during $2^{\text {nd }}$ year. This difference is due to the combined application of organic and inorganic fertilizers in the soil which provide maximum nutrient to the grain. Tahir et al. (2011) also observed increase in growth, yield and grain weight of wheat when applied nutrients through different organic sources.

\section{Number of grains spike $e^{-1}$}

Data on no. of grains spike ${ }^{-1}$ indicated significant difference in the treatment $\mathrm{T}_{8}(\mathrm{RF}+\mathrm{VC}+\mathrm{PSB})$ over treatment $\mathrm{T}_{1}$ (control). Maximum no. of grains spike ${ }^{-1}$ were 63 and 65 for the year 2017-18 and 2018-19, respectively whereas minimum grains spike ${ }^{-1}$ were recorded in treatment $\mathrm{T} 1$ (34 and 28 for both year) where no organic and inorganic input was applied. However, grains spike ${ }^{-1}$ also improved in other treatments where individual or combined organic and inorganic source was used. These results are similar to the findings of Khan and Hussain (2001), who found that the farm yard manure and different levels of nitrogen and phosphorous significantly increased the number of grains.

\section{Grain yield $\left(\mathrm{kg} \mathrm{ha}^{-1}\right)$}

In this study, highest grain yield $\left(2784 \mathrm{~kg} \mathrm{ha}^{-1}\right.$ and $3179 \mathrm{~kg} \mathrm{ha}^{-1}$ ) was recorded in the $\mathrm{T}_{8}$ treatment which was followed by $\mathrm{T}_{5}$ and $\mathrm{T}_{6}\left(572 \mathrm{kgha}^{-1}\right.$ and $\left.887 \mathrm{~kg} \mathrm{ha}^{-1}\right)$. During the year 2017-18 and 2018-19, the treatment $\mathrm{T}_{7}$ where vermicompost and $\mathrm{PSB}$ was applied depicted better grain yield $\left(1594 \mathrm{~kg} \mathrm{ha}^{-1}, 1628 \mathrm{~kg} \mathrm{ha}^{-1}\right)$ than control (Figure 1). This increase in grain yield may be due to the collective application of organic, inorganic and biological sources that enhanced nutrient status in soil. Davari et al. (2012) revealed that combined use of biofertilizers and organic material increased the wheat yield. Same consequences were also stated by Moe et al. (2019) that the combined nutrient application through organic and mineral sources improved the rice grain yield significantly over control. As yield and yield attributes mainly depends on efficient source but Barani Agricultural Research Institute (BARI), Chakwal located in the region where rainfall is mostly uneven and 70\% rainfall occurs during moonsoon season (July to September). Wheat yield is generally low due to such climatic constraints and insufficient use of inputs. (Punjab Development Statistics, 2013). Rainfall data was recorded from meteorological system installed in the Institute. It can be observed from the graph that rainfall pattern was different for both the year 2017-18 and 2018-19. During the first monsoon season maximum rainfall occur during July $(238 \mathrm{~mm})$ and August $(164 \mathrm{~mm})$ whereas during 2018-19 maximum rainfall occur in June-July ( $96 \mathrm{~mm}$ and $261 \mathrm{~mm}$ ) that left less moisture at the time of sowing but a continuous spell of rain 
from January 2019 to April 2019 occurred during the growing season of wheat that influence plant growth (Figure 2).

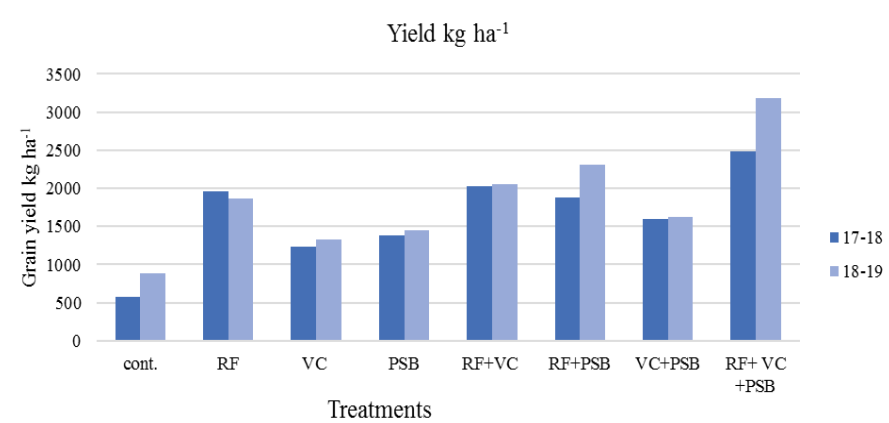

Figure 1: Effect of vermicompost and microbial inoculants and RDF on grain yield $\left(\mathrm{kg} \mathrm{ha}^{-1}\right)$ for $1^{\text {st }}$ year 2017-18 and $2^{\text {nd }}$ year 2018-19 respectively.

\section{Total Rainfall 2017-18 and 2018-19}

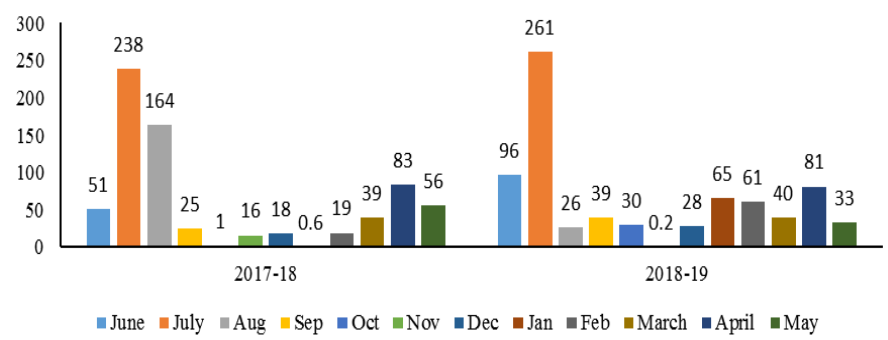

Figure 2: Total rainfall pattern in Barani agricultural research institute, Chakwal.

\section{Effect on soil fertility}

Post-harvest soil analysis was done and it was observed that soil fertility improved where organic sources fertilizers were applied. Application of VC @ $4 \mathrm{t} \mathrm{ha}^{-1}$ and microbial inoculant along with RF significantly increased $\mathrm{OM}$, available nitrogen, phosphorus and potash in soil over control. However, soil fertility improvement was observed in all treatments where organic and inorganic sources were applied except control. This improvement in soil health might be a factor that increase wheat yield. Pandey et al. (2009) also found improvement in soil fertility when FYM applied along with chemical fertilizers in wheat.

\section{Economic analysis}

For economic analysis, total production cost and total income were calculated separately. The total production included cost of POL for tillage practices, seed, Fertilizers, weedicides, vermicompost preparation cost, PSB and Threshing via combine harvester. These costs were calculated on the basis of inputs applied and then converted into per hectare area. Similarly output cost for grain and straw yield was calculated for all the treatments (Table 4).

\begin{tabular}{|c|c|c|c|c|}
\hline Treatments & OM (\%) & $\begin{array}{l}\mathrm{NO}_{3} \mathrm{~N} \\
\left(\mathrm{mg} \mathrm{kg}^{-1}\right)\end{array}$ & $\begin{array}{l}P \\
\left(\mathrm{mg} \mathrm{kg}^{-1}\right)\end{array}$ & $\begin{array}{l}\mathrm{K} \\
\left(\mathrm{mg} \mathrm{kg}^{-1}\right)\end{array}$ \\
\hline Control & 0.28 & 4 & 3.32 & 104.67 \\
\hline $\mathrm{RF}$ & 0.35 & 8 & 7.11 & 117.67 \\
\hline $\mathrm{VC}$ & 0.44 & 10 & 8.14 & 120.00 \\
\hline PSB & 0.30 & 6 & 6.11 & 101.00 \\
\hline $\mathrm{RF}+\mathrm{VC}$ & 0.48 & 11 & 8.34 & 121.67 \\
\hline $\mathrm{RF}+\mathrm{PSB}$ & 0.39 & 8 & 7.74 & 116.67 \\
\hline $\mathrm{VC}+\mathrm{PSB}$ & 0.46 & 10 & 8.48 & 109.67 \\
\hline $\mathrm{RF}+\mathrm{VC}+\mathrm{PSB}$ & 0.58 & 13 & 9.4 & 128.33 \\
\hline $\mathrm{CV}$ & 3.46 & 10.94 & 9.58 & 3.55 \\
\hline LSD & 0.03 & 1.7 & 1.23 & 7.15 \\
\hline
\end{tabular}

Table 4: Total input/ income cost and Output/production cost (Rs.).

$\begin{array}{lll}\text { Input/Management practices } & \begin{array}{l}\text { Cost ha }^{-1} \\ \text { (Rs.) }^{\mathbf{2 0 1 7 - 1 8}}\end{array} & \begin{array}{l}\text { Cost ha }^{-\mathbf{1}} \\ \text { (Rs.) }^{\mathbf{2 0 1 8}-19}\end{array} \\ \text { Seed (Certified seed) } & 6500 & 6875 \\ \text { Fertilizer (Urea, DAP, SOP) } & 19250 & 21250 \\ \text { Vermicompost } & 12500 & 12500 \\ \text { PSB inoculants (NARC) } & 1500 & 1500 \\ \text { Harvest (Rs. 1500 Acre-1) } & 3750 & 3750 \\ \text { Weedicide (Buctral Super; 3L ha }{ }^{-1} \text { ) } & 5000 & 5000 \\ \text { POL (Sowing, 03 tillages) } & 10000 & 12500 \\ \text { Total input cost } & 58500 & 63375 \\ \text { Total Output/Income Rs. ha }{ }^{-1} & 2017-18 & 2018-19 \\ \text { Grain Yield market Rate (Rs./40kg) } & 1200 & 1250 \\ \text { Straw market rate (Rs./40kg) } & 450 & 450\end{array}$

The economic analysis is the only tool, which compels the farmers to decide what to grow and what not to grow (Khan et al., 2009). Therefore, the economic analysis of agroecosystems is necessary for good management. Input cost of wheat in the first year varied from Rs. $25250 \mathrm{ha}^{-1}$ for the control to Rs. $72500 \mathrm{ha}^{-1}$ for $\mathrm{T}_{8}(\mathrm{RF}+\mathrm{VC}+\mathrm{PSB})$, and for $2^{\text {nd }}$ year from Rs. $28125 \mathrm{ha}^{-1}$ for the control to Rs. 63375 with treatment $\mathrm{T}_{8}$. The combined application of $\mathrm{RF}+\mathrm{VC}$ and microbial inoculants given in different treatments no doubt increased cost of production for $1^{\text {st }}$ year and for $2^{\text {nd }}$ year, but also increased net return as Rs. 50781 $\mathrm{ha}^{-1}$ and Rs. $83669 \mathrm{ha}^{-1}\left(\mathrm{~T}_{8}\right)$ for $1^{\text {st }}$ and $2^{\text {nd }}$ year over control i.e Rs. -97 ha $^{-1}$ and Rs. 12914 ha $^{-1}$ (Tables 5 and 6). The economic value of wheat cultivation was improved with integrated nutrient application of organic, inorganic and biological sources as reported by Sharma et al. (2000) and Singh and Prasad (2011). 
Table 5: Total Production cost and B: C for the year 2017-18.

$\begin{array}{llllllllll}\text { Trt } & \begin{array}{l}\text { Seed } \\ \text { (RS. /ha) }\end{array} & \begin{array}{l}\text { Fertilizers } \\ \text { (RS. /ha) }\end{array} & \begin{array}{l}\text { Weedicide } \\ \text { (RS. /ha) }\end{array} & \begin{array}{l}\text { Harvester } \\ \text { (RS./ha) }\end{array} & \begin{array}{l}\text { POL } \\ \text { (RS./ha) }\end{array} & \begin{array}{l}\text { T. Input } \\ \text { (RS. /ha) }\end{array} & \begin{array}{l}\text { T. output } \\ \text { (RS./ha) }\end{array} & \begin{array}{l}\text { Net } \\ \text { (Rs./ha) }\end{array} & \text { BC } \\ \text { T1 } & 6500 & 0 & 5000 & 3750 & 10000 & 25250 & 25153 & -97 & 1.00 \\ \text { T2 } & 6500 & 33250 & 5000 & 3750 & 10000 & 58500 & 86372 & 41872 & 1.48 \\ \text { T3 } & 6500 & 12500 & 5000 & 3750 & 10000 & 37750 & 54267 & 16517 & 1.44 \\ \text { T4 } & 6500 & 1500 & 5000 & 3750 & 10000 & 26750 & 58100 & 31350 & 2.17 \\ \text { T5 } & 6500 & 45750 & 5000 & 3750 & 10000 & 71000 & 89452 & 32452 & 1.26 \\ \text { T6 } & 6500 & 34750 & 5000 & 3750 & 10000 & 60000 & 82617 & 36617 & 1.38 \\ \text { T7 } & 6500 & 14000 & 5000 & 3750 & 10000 & 39250 & 70151 & 30901 & 1.79 \\ \text { T8 } & 6500 & 47250 & 5000 & 3750 & 10000 & 72500 & 109281 & 50781 & 1.51\end{array}$

Table 6: Total Production cost and B: C for the year 2018-19.

$\begin{array}{llllllllll}\text { Trt. } & \begin{array}{l}\text { Seed } \\ \text { (RS. /ha) }\end{array} & \begin{array}{l}\text { Fertilizer } \\ \text { (RS./ha) }\end{array} & \begin{array}{l}\text { Weedicide } \\ \text { (RS./ha) }\end{array} & \begin{array}{l}\text { Harvester } \\ \text { (RS./ha) }\end{array} & \begin{array}{l}\text { POL } \\ \text { (RS./ha) }\end{array} & \begin{array}{l}\text { T. Income } \\ \text { (RS. /ha) }\end{array} & \begin{array}{l}\text { T. Output } \\ \text { (RS./ha) }\end{array} & \begin{array}{l}\text { Net } \\ \text { (Rs./ha) }\end{array} & \text { BC } \\ \text { T1 } & 6875 & 0 & 5000 & 3750 & 12500 & 28125 & 41039 & 12914 & 1.46 \\ \text { T2 } & 6875 & 21250 & 5000 & 3750 & 12500 & 49375 & 86148 & 36773 & 1.74 \\ \text { T3 } & 6875 & 12500 & 5000 & 3750 & 12500 & 40625 & 61667 & 21042 & 1.52 \\ \text { T4 } & 6875 & 1500 & 5000 & 3750 & 12500 & 29625 & 64163 & 34538 & 2.17 \\ \text { T5 } & 6875 & 33750 & 5000 & 3750 & 12500 & 61875 & 95136 & 33261 & 1.54 \\ \text { T6 } & 6875 & 22750 & 5000 & 3750 & 12500 & 50875 & 106884 & 56009 & 2.10 \\ \text { T7 } & 6875 & 14000 & 5000 & 3750 & 12500 & 42125 & 75280 & 33155 & 1.79 \\ \text { T8 } & 6875 & 35250 & 5000 & 3750 & 12500 & 63375 & 147044 & 83669 & 2.32\end{array}$

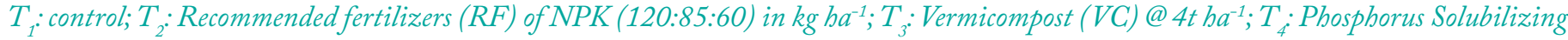
Bacteria (PSB); $T_{5}$ :Recommended fertilizers $(R F)+V C @ 4 t h a^{-1} ; T_{6}:$ Recommended fertilizers $(R F)+P S B ; T_{7}: V C @ 4 t h a^{-1}+P S B ; T_{8}:$ Recommended fertilizers $(R F)+V C @ 4 t h a^{-1}+P S B$.

\section{Conclusions and Recommendations}

Number of yield and yield attributes were positively affected with combined application of vermicompost PSB and chemical fertilizers. It is also evident that application of organic sources particularly vermicompost can be an excellent organic fertilizer which improved soil physical and chemical properties that was reflected in wheat growth and production. It can also be concluded that if vermicompost is applied in combination with chemical fertilizers can be an alternative substitute of applying chemical fertilizers alone. As vermicompost is rich source of nutrients but have lower quantities of NPK than chemical fertilizers, it has to be applied in bulk quantity which may become costlier and uneconomical hence it should be applied in combination with PSB and chemical fertilizers which will not only boost plant yield but also be economical.

\section{Novelty Statement}

Integrated application of mineral fertilizers along with microbial inoculants and vermicompost not only increase the wheat production and economic returns but also improve the soil health

\section{Author's Contribution}

Muhammad Arsaln: Conceived the idea, design and conducting experiment, paper writeup.

Sair Sarwar: Data recording, paper writeup and overall management of the article.

Rizwan Latif: Help in conducting experiment and data recoding.

Junaid Nawaz Chauhdary: Statistical analysis of data and arranging figures and tables.

Munazza Yousra: Data organization and paper review etc.

Shahbaz Ahmad: Technical inputs and provision of biofertilizer and compost for experiment

\section{Conflict of interest}

The authors have declared no conflict of interest. 
References

Ahmad, Z., M.Y. Mujahid, M.A. Khan, S. Yasmin, M. Asif and M. Qamar. 2010. NARC-2009: A high yielding wheat variety for rainfed areas of Pakistan. Pak. J. Agric. Res., 23: 1-4.

Anon. 2016. Pakistan economic survey 201516. Ministry of food and agriculture, Govt. of Pakistan, Islamabad, Pakistan.

Anonymous. 2007. Economic Survey of Pakistan 2006-2007. Government of Pakistan, Finance Division, Economic Advisory wing, Islamabad. Arsalan M., A. Ahmed, J.N. Chaudhary and M. Sarwar. 2016. Effect of vermicompost and Phosphorus on Crop growth and nutrient uptake in mungbean.J.Appl.Agric. Biotechnol., 1: 38-46.

Awan, T.H., R.I. Ali, Z. Manzoor, M. Ahmad and M. Akhtar. 2011. Effect of different nitrogen levels and row spacing on the performance of newly evolved medium grain rice variety, KSK133. J. Anim. Plant Sci., 21: 231-234.

Babu, S., R. Marimuthu, V. Manivanna and S.R. Kumer. 2001. Effect of organic and inorganic manures on growth and yield of rice. Agric. Sci. Digest., 21: 232-234.

Brahmachari, K., S.R. Choudhury, S. Karmakar, S. Dutta and P. Ghosh. 2011. Sustainable nutrient management in rice (Oryza sativa) Paira Chickling Pea (Lathyrus sativus) - Green gram (Vigna radiata) sequence to improve total productivity of land under coastal zone of West Bengal. Rajshahi Univ. J. Environ. Sci., 1: 5161.

Bremner, J.M. and D.R. Keeney. 1965. Steam distillation methods for determination of ammonium, nitrate, and nitrite. Anal. Chem. Acta. 32: 215-163. https://doi.org/10.1016/ S0003-2670(00)88973-4

Chanda, G.C., G. Bhunia and S.K. Chakraborty. 2011. The effect of vermicompost and other fertilizers on cultivation of Tomato plants. J. Hortic. For., 3: 42-45.

Dahiya, D.S., S.S. Dahiya, O.P. Cathwal, R. Sharma and R.S. Sheoran. 2008. Integrated nutrient management in wheat under rice-wheat cropping system. Haryana J. Agron., 24: 51-54.

Davari, M.R.1, S.N. Sharma and M. Mirzakhani. 2012. The effect of combinations of organic materials and biofertilisers on productivity, grain quality, nutrient uptake and economics in organic farming of wheat. J. Org. Syst., 7: 1177-

4258. https://doi.org/10.1186/2251-7715-114

Jack, L.H. and J.E. Thies. 2006. Compost and vermicompost as amendments promoting soil health. In book: Biological approaches to sustainable soil systems, publisher: CRC Press, Editors: Norman Uphoff, pp.453-466. https:// doi.org/10.1201/9781420017113.ch31

Khan, M.A., I.U. Awan and J. Zafar. 2009. Energy requirement and economic analysis of rice production in western part of Pakistan. Soil Environ., 28: 60-67.

Khan, A.M. and I. Hussain. 2001. Maturing effect on the potential grain yield of wheat in the light of Holy Quran. J. Biol. Sci., 1: 62-64. https:// doi.org/10.3923/jbs.2001.62.64

Kumar, K. and K.M. Goh. 1999. Crop residues and management practices: effects on soil quality, soil nitrogen dynamics, crop yield and nitrogen recovery. Adv. Agron., 68:197-319. https://doi. org/10.1016/S0065-2113(08)60846-9

Kumar, S. and Satya van. 2017. Effect of integrated nutrient management on growth and development of wheat (Triticum aestivum L.) under saline and canal water irrigation. Int. J. Pure Appl. Biosci., 5: 744-751. https://doi. org/10.18782/2320-7051.6113

Lal, R., 2004. Soil carbon sequestration impact on global climate change and food security. Science, 304: 1623- 1627. https://doi.org/10.1126/ science.1097396

Livleen, S., S.P.Tyagi, R. Manjunath, Jeetender and A.K. Saxena. 2013. Effect of vermicompost and microbial inoculants on soil health, growth and yield of HD 2687 wheat (Triticum aestivum). Indian J. Agric. Sci., 83(3): 340-343.

Maqsood M., A.M. Abid, A. Iqbal and M.I. Hussain.2001. Effect of variable rate of nitrogen and phosphorus on growth and yield of maize (golden). Online J. Biol. Sci., 1: 19-20. https:// doi.org/10.3923/jbs.2001.19.20

Meena, S.L., S. Surendra, Y.S. Shivay and S. Singh. 2003. Response of hybrid rice (Oryza sativa) to nitrogen and potassium application in sandy clay loam soils. Indian J. Agric. Sci., 73: 8-11.

Moe, K., S.M. Moh, A.Z. Htwe, Y. Kajihara and T. Yamakawa. 2019. Effects of integrated organic and inorganic fertilizers on yield and growth parameters of rice varieties. Rice Sci., 26(5): 309-318. https://doi.org/10.1016/j. 
rsci.2019.08.005

Olsen, S.R., C.V. Cole, F.S. Watanabe and L.A. Dean.1954. Estimation of available phosphorus in soils by extraction with sodium bicarbonate. U.S. Dept. Agric. Circ. 939, USA.

Pandey, I.B., Dwivedi, D.K. and R.K. Pandey. 2009. Integrated nutrient management for sustaining wheat (Triticum aestivum) production under late sown condition. Indian J. Agron., 54: 306309.

Patel, H.K., A.C. Sadhu, Y.C. Lakum and J.V. Suthar. 2014. Response of integrated nutrient Management on wheat (Triticum aestivum L.) and its residual effect on succeeding crop. Int. J. Agric. Sci. Vet. Med., 2: 2320-3730.

Punjab Development Statistics. 2013. Bureau of Statistics Government of the Punjab, 2-Begum Road, Lahore.

Pullicinoa, D.S., L. Massaccesia, L. Dixonb, R. Bolb and G. Gigliottia. 2009. Organic matter dynamics in a compost-amended anthropogenic landfill capping-soil. Eur. J. Soil Sci., 61: 35-47. https://doi.org/10.1111/j.13652389.2009.01198.x

Qazilbash, A.A., 2002. Population growth and its impact on environment. Popul. E Bull., 2: 4.

Rahman, S., W. Arshad, S. Ali, M. Hussain, M. Tariq, A. Mehmood and S. Niaz. 2012. BARS09: A high yielding and rust resistant wheat (Triticum aestioum L.) variety for rainfed areas of Punjab. J. Agric. Res., 50: 189-201.

Rather, S.A. and N.L. Sharma. 2010. Effect of integrated nutrient management on productivity and nutrient uptake in wheat and soil fetility. Asian J. Soil Sci., 4: 208-210.

Shad, K.K., A.Z. Khan, A.R. Baloch and P. Shah. 1999. Effect of row spacing and herbicides application on some agronomic characteristics of wheat (Triticun aestivum L.). Sarhad J. Agric., 15: 535-540.

Sharma, A.K., A.K. Kelcar, O.R. Mishra, S.S. Kushwaha and A.M. Rajput. 2000. Response of wheat of irrigated nutrient management under irrigated conditions. Res. Crops, 1: 105-107.

Shibu, M.E.,H.Van Keulen, P.A. Leffelaar and P.K. Aggarwal. 2010. Soil carbon balance of ricebased cropping systems of the Indo-Gangetic Plains. Geoderma, 160: 143-154. https://doi. org/10.1016/j.geoderma.2010.09.004

Singh, R.R. and K. Prasad. 2011. Effect of biofertilizer on growth and productivity of wheat (Triticum aestivum). Int. J. Farm Sci., 1(1): 1-8.

Steel, R.G., 1997. Analysis of covariance. Principles and procedures of statistics: A Biometrical Approach. pp. 401-437

Tahir, M., M. Ayub, H.M.R. Javeed, M. Naeem, H. Rehman, M. Waseem and M. Ali. 2011. Effect of different organic matter on growth and yield of wheat. Pak. J. Life Soc. Sci., 9: 63-66.

US Salinity Laboratory Staff, 1954. Diagnosis and improvement of saline and alkali soils. US Department of Agriculture Handbook 60, Washington, DC.

Walkley, A., 1947. A critical examination of a rapid method for determining organic carbon in soils: Effect of variations in digestion conditions and of organic soil constituents. Soil Sci., 63: 251-263. https://doi.org/10.1097/00010694194704000-00001

Weber, J., A. Karczewska, J. Drozd, M. Licmar, S. Licznar and E. Jarnroz. 2007. Agricultural and ecological aspects of a sandy soil as affected by the application of municipal solid waste composts. Soil Biol. Biochem., 39: 1294-1302. https://doi.org/10.1016/j.soilbio.2006.12.005 